Seminário de Pesquisa

Programa de Pós-Graduação

Design FAU USP

\title{
Estudo de reconhecimento de casos notáveis de design de serviço voltados ao setor público na cidade de São Paulo
}

Diego Luz de Carvalho, Luís Cláudio Portugal do Nascimento

\author{
design de serviço; setor público; design para serviços públicos
}

A pesquisa proposta tem por propósito realizar um estudo de reconhecimento de iniciativas relevantes na área dos serviços públicos (municipais, estaduais ou federais) na cidade de São Paulo, que em algum grau tenham sido desenvolvidas e/ou aperfeiçoadas pelo design de serviços. Esse levantamento de dados objetiva a identificação desses locais e a apreensão dos valores que foram gerados pela interação com o design de serviços, medidos por meio da avaliação de seus usuários e dos demais stakeholders desses serviços. Neste momento, ainda que não tenha sido iniciada a fase de levantamento de dados, pode-se ponderar o caminho a ser percorrido. O projeto, em linhas gerais, será desenvolvido por meio de técnicas de coleta de dados recorrentes em estudos da mesma natureza, em especial aqueles de cerne descritivo-observacional, como revisão bibliográfica, desk research, observações diretas de usuários, entrevistas semiestruturadas e, possivelmente, questionários. Tal panorama a ser desenhado é extremamente relevante para que se identifique as características comuns que são produtos diretos da metodologia de design aplicada a serviços que são estritamente públicos. As futuras constatações desse estudo se desvelarão pertinentes pois há a necessidade de se compreender, de fato, sob a ótica do cidadão, quais suas compreensões sobre a utilização de determinados serviços públicos, resultantes inerentemente da interação com o design de serviços. Dessa maneira, uma análise dessas percepções opera como justificativa para que mais gestores públicos se encorajem a desenvolver serviços a partir da aplicação de métodos do design.

\footnotetext{
Luís Cláudio Portugal do Nascimento

Professor da FAU USP, doutor em ensino do design pela New York University (1997), mestre pela École Nationale Supérieure d'Arts et Métiers, Paris (1987), e bacharel em desenho industrial e comunicação visual pela Escola Superior de Desenho Industrial da Uerj (1983).
}

e-mail: claudioportugal@usp.br

Lattes: http://lattes.cnpq. br/2797773827825547

Orcid: https://orcid.org/00000003-4586-1747 


\title{
Exploratory study of notable cases of service design in the public sector in the City of São Paulo
}

Diego Luz de Carvalho, Luís Cláudio Portugal do Nascimento

\author{
service design; public sector; design for public services
}

The purpose of the research project is to conduct a study to recognize relevant initiatives in the area of public services (municipal, state or federal) in the city of São Paulo, which in some degree have been developed and / or improved by service design methods. This data survey aims to identify those services and apprehend what values were generated by the interaction of service design thinking, valued through the appreciation of its users and all the other stakeholders of those services. At this moment, even though data collection phase has not started, the path to be followed can be forseen. The project, in general, will be developed using data collection techniques recurrent in studies of the same nature, especially those with a descriptive-observational core, such as bibliographic review, desk research, user observations, semi-structured interviews and, possibly, questionnaires. The project outcome to be drawn is extremely relevant in order to identify the common characteristics that are direct results of the design methodology applied to services that are strictly public.

Course

Master

\section{Line of Research}

Design: Processes and Languages

\section{Diego Luz de Carvalho}

Master's student in Design (Faculdade de Arquitetura e Urbanismo da Universidade de São Paulo). Bachelor of design from the same institution (2018). Currently working as a public servant for the Legislativa Assembly of São Paulo. e-mail: diegodecarv@usp.br Lattes: http://lattes.cnpq. br/3911621801256526

\section{Luís Cláudio Portugal}

\section{do Nascimento}

Professor at FAU USP. He holds a Ph.D. in art education from New York University (1997), a Masters Degree from École Nationale Supérieure d'Arts et Métiers, Paris (1987), and a Bachelors Degree in Graphic and Industrial Design from Escola Superior de Desenho Industrial (1983).

e-mail: claudioportugal@usp.br

Lattes: http://lattes.cnpq. br/2797773827825547

Orcid: https://orcid.org/00000003-4586-1747
Future findings of this study will be relevant as there is a need to understand, in fact, from the perspective of the citizen, what are their understandings about using certain public services, inherently resulting from the interaction with service design. Thus, an analysis of these perceptions operates as a justification for encouraging more public managers to develop services based on design methods.

\section{Referências | References}

GOODE, W. \& HATT, P. 1973. Métodos em Pesquisa Social. São Paulo: Editora Universitária.

RICHARDSON, R. J. 2017. Pesquisa Social, Métodos e Técnicas. São Paulo: Editora Atlas.

STICKDORN, M. \& SCHNEIDER, J. 2014. Isto é Design Thinking de Serviços. Porto Alegre: Bookman. 